University of Warwick institutional repository: http://go.warwick.ac.uk/wrap This paper is made available online in accordance with publisher policies. Please scroll down to view the document itself. Please refer to the repository record for this item and our policy information available from the repository home page for further information.

To see the final version of this paper please visit the publisher's website. access to the published version may require a subscription.

Author(s): Mark Harrison

Article Title: The Rational-Choice Dictator - A Reply

Year of publication: 2006

Link to published version: http://dx.doi.org 10.1080/09668130600926454

I

Publisher statement: None 


\title{
The Rational-Choice Dictator: Reply*
}

\author{
Mark Harrison $^{* *}$
}

In a recent survey Vincent Barnett has criticised my application of the theory of rational choice to Stalin's actions and decisions. He suggests that I represent a misguided tendency of the "traditional left" to seek to rescue "something 'rational'" from the Soviet experience of Stalin's rule. Rather, he argues, Stalin's actions were characterised by "'pseudo-rational choice irrationality,' or apparently rational actions that only appear rational from the point of view of a dictator paranoid about his own position, paranoid about the position of the USSR internationally, and having a very tenuous grasp of economic theory, the intellectual genesis of Marxism and the consequences of tyrannical rule for the Soviet state and governmental institutions. But this is not real 'rationality' ...". ${ }^{1}$

I leave to one side the issue of my political orientation, past or present, which should be irrelevant to the present discussion. What matters here is the question of how best to understand Stalin's beliefs and actions. As a concept, rationality can of course be defined and applied in more than one way. I acknowledge that my own sense of the word comes from a particular tradition in social science. At the same time, I believe that this tradition is of more value in the given context than would appear from Barnett's discussion of it.

\section{Why Rational Choice?}

The theory of rational choice is a tool of the economist's trade. We use it as a dictator might use his secret police - not for propaganda, but as a powerful and parsimonious means of investigation. The idea rests on three assertions.

First, people choose; they are not driven. We observe this even in the most hierarchical and coercive contexts that exist. Prisons cannot be managed without complex mechanisms to subdue, divide, and divert those

* Published in Europe-Asia Studies 58:7 (2006), pp. 1148-1154.

** Professor of Economics, University of Warwick; Senior Fellow, Centre for Russian and East European Studies, University of Birmingham; Distinguished Visiting Fellow, Hoover Institution on War, Revolution, and Peace, Stanford University. Mail: Department of Economics, University of Warwick, Coventry CV4 7AL, United Kingdom. Email: mark.harrison@warwick.ac.uk. I thank Chuck Blackorby, R.W. Davies, Sayantan Ghosal, and Peter Law for advice.

${ }^{1}$ Vincent Barnett, "Understanding Stalinism - The 'Orwellian Discrepancy' and the 'Rational Choice Dictator'," Europe-Asia Studies, 58:3 (2006), pp. 457466, on pp. 461, 464.

First draft: 4 June 2006. This version: 13 June 2006. 
that they confine, who otherwise may prefer to mutiny. Armies also require complex institutions to bind the individual soldier willingly into the collective; otherwise, he is likely to desert before the battle. From this perspective the very existence of groups and collectives such as military units depends on the willing choice of the individual persons that make them up to participate continually and not to defect.

A second assertion is that the choices that people make can be understood: people do as they choose in conformity with their preferences, subject to the resources available and the information that they have.

The third is that, when a person chooses to incur a cost that could otherwise be avoided, there must be some expected benefit to them that is equal to or greater than the cost.

The theory of rational choice may be used in different ways. If we can observe costs and allocations, for example, it allows us to infer preferences. Alternatively, on the basis of observed costs and assumed preferences, we can make testable predictions about allocations; and so on. It is parsimonious because it simplifies to extremes. In the case of the actions of a dictator, for example, it encourages us to give logical priority to motivations that are general ("Stalin killed a million people in 1937 because he believed this would insure his regime") over those that are idiosyncratic ("Stalin killed a million people in 1937 because of a quirk in his personality"). Each statement may be true in some sense. I acknowledge that the biographer or the psychiatrist may find more interest in the latter. ${ }^{2}$ But the former is more promising in scope for the generalisation of social science knowledge.

It is true that in recent years economists have become more open to the investigation of limits on rational choice. Rationality is usually taken to imply that agents either optimise continually, or behave "as if" they do, or are negatively selected if they don't. But to search continually for the optimum may itself be costly. The literature on bounded rationality examines how, for example, agents who prefer to avoid the costs of deliberation may rationally replace optimisation with a rule of thumb. ${ }^{3}$ Barnett places much emphasis on the lack of economic logic in Politburo deliberations and Stalin's ignorance of economic principles as a barrier to rational calculation. ${ }^{4}$ Paul Gregory, in contrast, has used Politburo records and the correspondence of its members to reconstruct Stalin's model of the Soviet economy and infer the rules that he may have followed when he made his decisions. ${ }^{5}$

${ }^{2}$ Thanks to Peter Law for this point.

3 For example John Conlisk, "Why Bounded Rationality?" Journal of Economic Literature, 34:2 (1996), pp. 669-700.

${ }^{4}$ Barnett, "Understanding Stalinism," pp. 463 and 465.

${ }^{5}$ Paul R. Gregory, The Political Economy of Stalinism (Cambridge: Cambridge University Press, 2004), pp. 76-109. Paul R. Gregory and Mark Harrison, "Allocation Under Dictatorship: Research in Stalin's Archives," Journal of Economic Literature, 43:3 (2005), pp. 721-61, on pp. 731-4, discuss the Politburo's "accumulation model" as a rule of thumb. 
In the field of behavioural economics, another literature has looked at various apparent violations of the requirements that rational preferences should be complete, non-satiated, transitive, and convex. The violations that are most commonly observed range from revealed preferences for equity and territoriality to loss aversion, addiction, and hyperbolic discounting. ${ }^{6}$ Here, too, it seems likely that these behaviours, if not closely related to "rational" preferences, are nonetheless formed on some other basis that we can still understand in economic terms. ${ }^{7}$

Contemporary witnesses and historians have come to share a common vocabulary in describing certain regularities in Stalin's behaviour. It is said, for example, that he tended to be capricious, intransigent, paranoid, and vindictive. In my paper I maintain only that these patterns do not require explanation in terms of Stalin's individual psychopathology. I do not object to use of the term "paranoia" as long as it is understood as metaphor, not clinical diagnosis. The analysis of principal and agent in a political hierarchy provides simpler, more encompassing explanations.

Ronald Wintrobe, for example, has suggested that paranoia in the metaphorical sense is the rational outcome of a "dictator's dilemma": the more powerful the dictator, the less he should trust the expressions of loyalty of those around him. ${ }^{8}$ In the paper that Barnett has criticised I offered a simple extension: "we may suppose that a dictator risks two types of error: excessive suspiciousness may lead him to see conspiracies everywhere, including some that do not really exist; if he trusts too much he may fail to unmask genuine conspiracies. Of course not all conspiracies will be seditious; many will be merely corrupt. But it is not hard to see that a risk-averse dictator is likely to prefer the first risk to the second." ${ }^{\prime 9}$ Still, he cannot do without trust altogether. As a further extension, the same dictator could improve his outcomes by switching randomly between trust and suspicion; a reputation for unpredictable or capricious changes of mind is a likely byproduct of this strategy. ${ }^{10}$

${ }^{6}$ For example Graham Loomes, Chris Starmer, and Robert Sugden, "Observing Violations of Transitivity by Experimental Methods," Econometrica, 59:2 (1991), pp. 425-39.

${ }^{7}$ For example H. Lorne Carmichael and W. Bentley MacLeod, "Welfare Economics with Intransitive Revealed Preferences: A Theory of the Endowment Effect," Journal of Public Economic Theory, 8:2 (2006), pp. 193218). Thanks to Chuck Blackorby for this reference.

${ }^{8}$ Wintrobe, Ronald, The Political Economy of Dictatorship (Cambridge: Cambridge University Press, 1998), pp. 20-36.

${ }^{9}$ Mark Harrison, "Stalin and Our Times," In Geoffrey Roberts (ed.), Stalin: His Times and Ours (Dublin: Irish Association for Russian and East European Studies, 2005), pp. 67-84, on p. 70.

${ }^{10}$ Thanks to Sayantan Ghosal for this point. 
There may be some confusion between the private rational choice of individuals and issues of social rationality. ${ }^{11}$ There is a long tradition of empirical inquiry by western economists into whether or not Soviet plans, prices and costs, investment criteria, and trade relations conformed to principles of social rationality. ${ }^{12}$ Abram Bergson famously proposed that rationality in this sense was measurable, and should be measured against two alternative yardsticks, consumer welfare and "planners' preferences." ${ }^{13}$ My own paper was not concerned with social rationality and suggested only that it is fruitful to enquire into Stalin's decisions on the basis of their private rationality. Take his rearmament decisions, for example. Economists usually classify military power as a public good; in my paper I made the rather obvious point that in the case of a dictator such as Stalin any investigation ought to take into account his calculus of the private benefits and costs that would result from building up the Red Army and a powerful defence industry. ${ }^{14}$

In addition to perhaps confusing what is meant by rational choice, Barnett charges me with four specific errors to which I now turn.

\section{Defending Stalin's Rationality?}

Barnett suggests that I am engaged in "defending Stalin's rationality." ${ }^{15}$ By this, he may mean that I defend the proposition that Stalin was rational as a matter of fact. From the standpoint of the political economist, however, "Stalin was a rational dictator" is not a statement of fact but a hypothesis that allows scholarly investigation to proceed. It is the beginning of an enquiry. In contrast, the statements "Stalin was paranoid" and "Stalin was ignorant" are finishing points; they close off further investigation, since they ascribe his actions to specific states of mind for which social science can have no explanation.

${ }^{11}$ For example Barnett, “Understanding Stalinism," p. 464, contrasts “a system of rational planning based on real human needs" with the actually existing "system of (partial) irrationality, or lagged institutional overhang from the Tsarist and World War I periods."

12 Gregory Grossman, "Scarce Capital and Soviet Doctrine," Quarterly Journal of Economics, 67:3 (1953), pp. 311-343; Steven Rosefielde, "Factor Proportions and Economic Rationality in Soviet International Trade 19551968," American Economic Review, 64:4 (1974), pp. 670-681; Phillip Weitzman, "Soviet Long-Term Consumption Planning: Distribution According to Rational Need," Soviet Studies, 26:3 (1974), pp. 305-321; Peter J.D. Wiles, “Are Adjusted Rubles Rational?" Soviet Studies, 7:2 (1955), pp. 143-160.

${ }^{13}$ Abram Bergson, The Economics of Soviet Planning (Yale University Press: New Haven and London, 1964), pp. 327-9.

\footnotetext{
${ }^{14}$ Harrison, "Stalin," p. 76.

${ }^{15}$ Barnett, “Understanding Stalinism,” p. 463.
} 
I believed that I had made this clear in the paper to which Barnett refers, when I wrote: "rational choice theory presents us with an intellectual challenge: if people do what they want, subject to the resource and information constraints that we can identify, and if we do not understand what they do, then we are missing something important and we should not be satisfied to throw up our hands." 16

Barnett prefers the idea of a Stalin gripped by a "power mania with deepseated psychological, sociological, and intellectual roots" to one "playing a mathematically modelled game of 'chicken' using the latest inventions of game theory at an instinctual level."17 In my own paper I wrote: "We need not suppose that Stalin engaged in the backward induction of a game theorist to compute his best choices. Instinct seems to lead many who desire to dominate others to the same equilibrium as calculation. Aspirant dictators must undergo a rigorous selection in the course of which those who lack the necessary instincts and tastes are likely to fall out or be pushed aside. Nor does this mean that dictators do not miscalculate: all who compete for power may make mistakes, but some will achieve power before they make ones that are serious." ${ }^{18}$

Now let me go further: Stalin's strategies were hardly "the latest inventions" of game theorists. When mathematicians and social scientists wrote these games down for the first time in the 1950s and 1960s, they did not invent them! Rather, they worked from observation. What John Nash's "beautiful mind" gave us was not the games themselves, which are as old as the history of human interaction, but a way of writing them down to understand them better. As social scientists, should we throw this away just because it is formalised for the sake of rigour?

\section{Defending Stalin's Morality?}

From other remarks, I fear Barnett may mean that I am defending not Stalin's rationality but his morality. He writes: "it sometimes seems to be tacitly implied in the literature that, as has been usefully shown by Davies and his co-workers using new archive materials, because the Stalinist system is now seen to be much more complex than had been previously described, involving some attempts at reform and many examples of inter and intrainstitutional conflict, it should be regarded as somehow less totalitarian, less dictatorial, less utterly horrific or less comparable to Nazism. ... Scholars should guard against the meaning of the word 'understanding' as it is used in this context from sliding from 'neutrally comprehending the factual particulars of the subject' to 'some hidden sympathy for Stalin's predicament'." While "studying the detail of Stalin's rule is ... a completely

\footnotetext{
${ }^{16}$ Harrison, "Stalin," p. 68.

${ }^{17}$ Barnett, “Understanding Stalinism,” p. 462.

${ }^{18}$ Harrison, "Stalin," p. 70.
} 
legitimate activity for historians," Barnett concludes, "the temptation to use this detail as valediction [validation?] should be resisted." ${ }^{19}$

Barnett and I are in agreement that the endorsement of Stalin's rule is not a proper purpose of scholarship. But where is the target of his criticism? I find no evidence for it; indeed, it does not rely on the evidence of what Davies, Harrison, or Wheatcroft have actually written. Rather, Barnett lays claim to a privileged ability to detect our hidden sympathies and a superior right to warn the unwary reader against our tacit implications.

\section{Stalin and Hitler: Double Standards?}

Barnett suggests that, with others, I might employ double standards were I to compare Hitler's and Stalin's dictatorships. Thus: "To suggest that Stalin rationally calculated the minimum level of murderous terror that he had to generate in order to maintain his own position ... is stretching the meaning of the word 'rational' into its opposite. Would Harrison suggest that Hitler also made a similar calculation in Germany, and hence Hitler was also acting 'rationally' by murdering Jews?" ${ }^{20}$ And: "the fact that ... the Soviet terror involved constituencies and group alliances and also zigzags of 'excesses' and 'normalisation', [does not] mean that Stalin was not ultimately responsible or that he was not a tyrant on a level with Hitler ... As Harrison no doubt knows full well, Hitler himself did not initially start out with a fully developed plan to murder all Jews in concentration camps. Rather, this policy developed over time, but this does not make Hitler any less responsible. ${ }^{21}$ In short, Barnett suggests, if the crime was homicide, I would find Stalin to have been both more calculating than Hitler and less guilty, and I would be wrong on both counts.

I would be disappointed with myself had I actually said these things. It is, after all, an established principle that premeditation increases the severity of the crime. But these are not my views. In my paper I discussed two issues, one the degree of intentionality behind Stalin's crimes and the other the degree of idealism behind the intentions. Of the latter, I wrote: "I do not attach much significance to it. If a killing was idealistically motivated, then this should inform our evaluation of the ideals, not of the guilt for the death." As for the former, it has been obvious for many years that Stalin intentionally had at least a million people put to death, while some of his policies also had the by-product of killing many more; in the case of the latter the degree of intentionality is debatable but, on balance, I suggested, "under Stalin manslaughter appears to have predominated, whereas Hitler was mainly a murderer." I concluded: "From some points of view a system that kills people

\footnotetext{
${ }^{19}$ Barnett, “Understanding Stalinism," pp. 464-5.

${ }^{20}$ Barnett, “Understanding Stalinism," p. 462.

${ }^{21}$ Barnett, “Understanding Stalinism,” p. 465.
} 
without premeditation may be regarded as worse than one that only kills them if the intention to do so is present in the mind of the ruler." ${ }^{22}$

Hitler's rationality is not for me to assess here, but the reader with a genuine interest in rational choice could consult Ed Glaeser's recent essay on "The Political Economy of Hatred." ${ }^{23}$

\section{The Last Justification?}

Barnett suggests that, with others, I would see economic development as the last justification of Stalin's rule: "for those of the Harrison-Davies school," he writes, "the final line in the sand for defending Stalin's 'rationality' relates to the development of the Soviet economy." 24 This justification, he maintains, is false: "a key point that both Harrison and Davies often neglect is that a socialist economy (as outlined initially by Marx) had absolutely nothing whatsoever to do with industrialisation. Socialist planning was supposed to be about improving the quality of all human life ..., not manufacturing vastly more iron and steel by means of a tyrannical forced labour system ...". ${ }^{25}$

While I am honoured to be associated with the work of R.W. Davies and Stephen Wheatcroft in any way, I do not hold the view that Barnett attributes to us; specifically, I do not think that Soviet economic development either promoted socialist ideals or provided a justification for Stalin's rule. Rather, widespread socialist ideas based on fear of the market economy and class warfare against rich people created an opportunity for Bolshevik leaders to mobilise their followers around a programme of industrialisation based on confiscation and forced accumulation.

More generally I follow the late Mancur Olson in ascribing the adoption of this programme, in large part, to the structure of a proprietary dictatorship. ${ }^{26}$ In my paper, however, I qualified this view as follows: "Stalin chose a path that simultaneously built up the industrial production of the planned economy and the military might of the Red Army. He chose guns, machinery, and a little butter for the workers, although the farmers occasionally starved and often had to content themselves with nettle soup. Was this choice a general feature of dictatorships of the Stalin type, or was it conditional upon the particular time and place? I am tempted to see it as contingent upon two historical circumstances: the size of the territory over which Stalin ruled, and its coincidence with the eras of mass production and mass warfare ... Fifty years later the world has moved on ... Probably, even if he were able to, a

${ }^{22}$ Harrison, "Stalin," p. 74; I have added the emphasis.

${ }^{23}$ Edward L. Glaeser, "The Political Economy of Hatred," Quarterly Journal of Economics, 120:1 (2005), pp. 45-86.

${ }^{24}$ Barnett, “Understanding Stalinism," p. 463

${ }^{25}$ Barnett, “Understanding Stalinism," p. 462

${ }^{26}$ Mancur Olson, "Dictatorship, Democracy, and Development," American Political Science Review, 87:3 (1993), pp. 567-76. 
Stalin of today would not wish to resurrect the industrial policies of the old Soviet Union." 27

To conclude, I thank Vincent Barnett for directing attention to my paper, but I wish that he had read it more attentively. If he had hoped to make significant inroads on the idea of the rational dictator, moreover, there are many more substantial targets. Mancur Olson's seminal paper on the political economy of dictatorship, recent monographs on the same theme by Ronald Wintrobe, Paul R. Gregory, and Daron Açemoglu and James Robinson, and the new research on Stalinism surveyed recently by Gregory and myself, are all more deserving of scrutiny than my own work. ${ }^{28}$

${ }^{27}$ Harrison, “Stalin," p. 78.

${ }^{28}$ Daron Açemoglu and James A. Robinson, Economic Origins of Dictatorship and Democracy (Cambridge: Cambridge University Press, 2005); Gregory, Political Economy of Stalinism; Gregory and Harrison, "Allocation Under Dictatorship"; Olson, "Dictatorship"; Wintrobe, Political Economy. 